\title{
Orchidftgra
}

\author{
Vol. 1, No. 1, Bulan Februari Tahun 2021 \\ DOI: http://dx.doi.org/10.35138/orchidagro.v1.i1.259
}

\section{Pengaruh Konsentrasi Dan Lama Inkubasi Kolkisin Terhadap Duplikasi Kromosom Planlet Terung (Solanum melongena L.) Haploid Galur Aksesi Hasil Kultur Antera}

\author{
Sopian Zayid, Agus Surya Mulya dan Yana Taryana \\ Program Studi Agroteknologi Fakultas Pertanian Universitas Winaya Mukti \\ Email: sopian.zayid@gmail.com
}

(Received: 04-01-21; Published: 20-02-21)

\begin{abstract}
.
The purpose of this study was to determine the effect of colchicine on chromosome duplication and to determine the best colchicine concentration and incubation time for haploid eggplant chromosome duplication results from anther culture. Laboratory experiments have been carried out at PT. East West Seed Indonesia, Benteng Village, Campaka District, Purwakarta from March to June 2020. With an altitude of $69 \mathrm{~m}$ above sea level. The environmental design used in this study was a completely randomized design consisting of 7 treatments and repeated 4 times. Colchicine treatment design $A=$ Control, $B=$ colchicine $0.05 \% 24$ hours incubation, $C=$ colchicine $0.05 \% 48$ hours incubation, $D=$ colchicine $0.1 \% 24$ hours incubation, $E=$ colchicine $0.1 \% 48$ hours incubation, $F=k o l k i s i s n ~ 0.15 \%$ incubation 24 hours, $G=$ colchicine $0.15 \%$ incubation 48 hours. The responses observed were contamination, callous plantlets, rooted plantlets, live plantlets, haploid plantlets, double haploid plantlets, triploid plantets and unreadable ploidy check results. The results showed that the colchysis concentration and incubation time had an effect on the duplication of haploid eggplant plantlet chromosomes resulting from anther culture. And giving colchicine at a concentration of $0.05 \%$ with an incubation time of 48 hours and a colchicine concentration of $0.1 \%$ with an incubation time of 48 hours had a significant effect on the double haploid plantet of $23.44 \%$.

Keywords: Colchicine, Cromosome Duplication, Doubled Haploid, Eggplant, Haploid.
\end{abstract}

ABSTRAK.

Tujuan dari penelitian ini adalah untuk mengetahui pengaruh kolkisin terhadap duplikasi kromosom dan untuk mengetahui konsentrasi dan lama inkubasi kolkisin yang terbaik terhadap duplikasi kromosom planlet terung haploid hasil kultur antera. Percobaan laboratorium telah dilaksanakan di PT. East West Seed Indonesia, Desa Benteng, Kecamatan Campaka, Purwakarta pada bulan Maret sampai Juni 2020. Dengan ketinggian tempat $69 \mathrm{~m}$ di atas permukaan laut. Rancangan lingkungan yang digunakan dalam penelitian ini adalah Rancangan Acak Lengkap yang terdiri dari 7 perlakuan dan diulang 4 kali. Rancangan perlakuan pemberian kolkisin $\mathrm{A}=\mathrm{Kontrol}, \mathrm{B}=\mathrm{kolkisin} 0,05 \%$ Inkubasi 24 jam, $\mathrm{C}=$ kolkisin 0,05\% inkubasi 48 jam, $\mathrm{D}=$ kolkisin $0.1 \%$ inkubasi 24 jam, $\mathrm{E}=$ kolkisin $0.1 \%$ inkubasi 48 jam, $\mathrm{F}=$ kolkisisn $0.15 \%$ inkubasi 24 jam, $\mathrm{G}=$ kolkisin $0.15 \%$ inkubasi 48 jam. Respon yang diamati yaitu kontaminasi, planlet berkalus, planlet berakar, planlet hidup, planlet haploid, planlet haploid ganda, plantet triploid dan hasil cek ploidy tidak terbaca. Hasil penelitian menunjukan bahwa konsentrasi kolkisisn dan lama inkubasi berpengaruh terhadap duplikasi kromosom planlet terung haploid hasil kultur antera. Dan pemberian kolkisisn pada 
konsentrasi 0,05\% dengan lama inkubasi 48 jam dan konsentrasi kolkisin 0,1\% dengan lama inkubasi 48 jam memberikan pengaruh nyata terhadap plantet haploid ganda sebesar $23.44 \%$.

Kata Kunci: Duplikasi Kromosom, Haploid, Haploid Ganda, Kolkisin, Terung.

\section{PENDAHULUAN}

Terung (Solanum melongena L) merupakan salah satu komoditas hortikultura penting yang banyak dibudidayakan petani Indonesia. Di Indonesia terung ditanam sekitar 43.905 ha dengan produktivitas pada tahun 2017 mencapai 12.19 ton/ha (Kementan, 2017). Angka tersebut masih jauh lebih rendah dari potensi produktivitas terung maksimal, yaitu 40 ton/ha (Yanik et al., 2017). Rendahnya produktivitas disebabkan oleh rendahnya penggunaan benih unggul, budidaya tanaman yang belum intensif, perubahan iklim dan serangan hama/penyakit yang tinggi (Pitojo, 2010). Untuk meningkatkan produktivitas terung salah satunya dengan menggunakan benih unggul. Benih unggul terung berasal dari varietas hibrida. Penggunaan varietas hibrida lebih disukai petani karena produktivitasnya tinggi (Kementan, 2017).

Varietas hibrida adalah varietas unggul hasil persilangan dua galur murni yang berbeda atau berkerabat jauh, sehingga muncul fenomena heterosis. Untuk mendapatkan varietas hibrida diperlukan tetua terpilih dengan tingkat keragaman genetik yang tinggi. Biasanya tetua hibrida berasal dari galur murni yang terseleksi. Galur murni adalah generasi yang berasal dari satu induk yang telah terseleksi dan memiliki tingkat keseragaman genotipe dan fenotipe yang tinggi. Penyediaan galur murni dapat diperoleh secara konvensional dengan melalui penyerbukan sendiri dan seleksi, namun metode tersebut memerlukan biaya yang besar dan waktu yang lama hingga 5-6 generasi. Penyediaan galur murni dapat dipersingkat dengan menggunakan teknologi haploid ganda (Seguí-Simarro, 2010).

Tanaman haploid adalah tanaman yang memiliki jumlah kromosom setengah dari jumlah kromosom somatiknya (Kasha and Maluszynski,
2003). Tanaman haploid dapat diperoleh melalui beberapa metode, seperti hibridisasi interspesies, penyerbukan dengan serbuk sari yang diiradiasi dan secara in vitro, dimana gametofit yang belum matang dikultur sehingga menghasilkan embrio haploid. Haploidisasi secara in vitro biasanya dilakukan melalui teknik kultur antera, kultur mikrospora, kultur ovul atau ovary (Poehlman and Sleper, 2015).

Tanaman haploid belum dapat digunakan karena tanaman tersebut steril atau tidak dapat menghasilkan keturunan. Fertilitas tanaman haploid dapat dikembalikan melalui penggandaan kromosom (George et al., 2008). Tanaman haploid ganda atau tanaman dihaploid mempunyai dua set kromosom yang identik dengan bentuk haploidnya serta dapat membentuk sel kelamin jantan dan sel telur seperti tanaman diploid (Kasha and Maluszynski, 2003).

Di PT. East West Seed Indonesia (Ewindo) produksi tanaman haploid ganda dilakukan melalui teknik kultur antera. Tanaman haploid ganda dapat diperoleh secara spontan melalui teknik kultur antera namun persentasenya cukup rendah yakni 20\%. Untuk itu dari $80 \%$ tanaman haploid yang didapat perlu digandakan supaya menjadi tanaman haploid ganda. Sementara ini metode yang dilakukan di Ewindo adalah teknik rendam embrio dengan kolkisin dengan persentase hasil 16\% (Mulyana, 2016).

Kolkisin diketahui sebagai agen antimitotik yang efektif dalam proses penggandaan kromosom (Solmaz et al., 2011). Berbagai metode dapat digunakan untuk menerapkan kolkisin dalam kultur in vitro salah satunya menambahkan larutan kolkisin ke media pertumbuhan dalam kultur in vitro (Yetisir and Sari, 2003). Penggunaan kolkisin dengan konsentrasi yang tepat dapat mengefektikan 
proses penggandaan kromosom. Setiap jenis tanaman memiliki respon yang berbeda-beda terhadap pemberian kolkisin, umumnya kolkisin akan bekerja efektif pada konsentrasi 0.01\%-1\% untuk jangka waktu 6-72 jam (Suminah et al., 2002). Oleh karena itu, penting untuk mengetahui berbagai konsentrasi dan lama inkubasi kolkisin terhadap tanaman khususnya terung.

\section{METODE DAN BAHAN}

Penelitian ini dilaksanakan dengan pendekatan eksperimen yaitu melalui percobaan laboratorium. Percobaan dilakukan dari bulan Maret sampai Juni 2020 di laboratorium bioteknologi PT. East West Seed Indonesia, Desa Benteng, Kecamatan Campaka, Purwakarta. Secara geografis terletak pada koordinat 1070 29'39'E dan 60 30'48'S dengan ketinggian tempat $69 \mathrm{~m}$ di atas permukaan laut.

Bahan yang digunakan dalam percobaan ini diantaranya planlet terung haploid yang didapat dari hasil kultur antera, media duplikasi (MS, Gula, Agar dan Kolkisin) $\mathrm{HCl}$ dan $\mathrm{NaOH}$ petridish plastik, filter $0,2 \mu \mathrm{m}$, alkohol $70 \%$,
Buffer cek ploidy (TrisMgCl, RNAse dan Propidium Iodide) dan media perakaran (MS, Gula dan Agar). Alat-alat yang digunakan yaitu timbangan analitik, botol schott, gelas ukur, magnetic steerer $\mathrm{pH}$ meter, autoclave, laminar air flow, Pinset, pisau scalpel, heater (glass bead sterilizer, kabinet $25^{\circ} \mathrm{C}$, mesin cek ploidy Guava, plate, pipet multichanel, filter plate mesh nilon 48- $\mu \mathrm{m}$, centrifuge dan thermometer.

Rancangan lingkungan menggunakan Rancangan Acak Lengkap (RAL), yang terdiri dari 7 perlakuan dan 4 ulangan yang terdiri dari Kontrol (tanpa pemberian kolkisin, Kolkisin $0.05 \%$ Inkubasi 24 jam, Kolkisin 0.05\% Inkubasi 48 jam, Kolkisin $0.1 \%$ Inkubasi 24 jam, Kolkisin $0.1 \%$ Inkubasi 48 jam, Kolkisin $0.15 \%$ Inkubasi 24 jam dan Kolkisin 0.15\% Inkubasi 48 jam Respon yang diamati yaitu Kontaminasi, Planlet Berkalus, Planlet Berakar, Planlet hidup, Planlet haploid, Planlet haploid ganda, Planlet triploid dan Hasil cek ploidy tidak terbaca Pelaksanaan percobaan meliputi pembuatan media duplikasi, aplikasi perlakuan dan cek ploidy.

\section{HASIL DAN PEMBAHASAN}

Tabel 1. Pengaruh Konsentrasi Kolkisin terhadap kontaminasi, Planlet Berkalus, Planlet Berakar, Planlet Hidup, Planlet Haploid, Planlet Haploid Ganda, Planlet Triploid dan hasil Yng tidak terbaca planlet pada umur 3 minggu setelah perlakuan.

\begin{tabular}{ccccccccc}
\hline & \multicolumn{7}{c}{ Rata-rata \% } \\
\cline { 2 - 8 } Perlakuan & Kontaminasi & $\begin{array}{c}\text { Planlet } \\
\text { Berkalus }\end{array}$ & $\begin{array}{c}\text { Planlet } \\
\text { Berakar }\end{array}$ & $\begin{array}{c}\text { Planlet } \\
\text { Hidup }\end{array}$ & $\begin{array}{c}\text { Planlet } \\
\text { Haploid }\end{array}$ & $\begin{array}{c}\text { Planlet } \\
\text { Haploid } \\
\text { Ganda }\end{array}$ & $\begin{array}{c}\text { Planlet } \\
\text { Triploid }\end{array}$ & $\begin{array}{c}\text { Hasil Tidak } \\
\text { Terbaca }\end{array}$ \\
\hline $\mathrm{A}=$ Kontrol & $0,00 \mathrm{a}$ & $1,56 \mathrm{a}$ & $64,06 \mathrm{a}$ & $100,00 \mathrm{a}$ & $100,00 \mathrm{~b}$ & $0,00 \mathrm{a}$ & $0,00 \mathrm{a}$ & $0,00 \mathrm{a}$ \\
$\mathrm{B}=0,05-24$ & $1,56 \mathrm{a}$ & $7,81 \mathrm{a}$ & $60,94 \mathrm{a}$ & $100,00 \mathrm{a}$ & $79,69 \mathrm{a}$ & $14,06 \mathrm{~b}$ & $0,00 \mathrm{a}$ & $6,26 \mathrm{a}$ \\
$\mathrm{C}=0,1-24$ & $26,56 \mathrm{a}$ & $3,31 \mathrm{a}$ & $62,50 \mathrm{a}$ & $85,94 \mathrm{a}$ & $68,75 \mathrm{a}$ & $14,06 \mathrm{~b}$ & $0,00 \mathrm{a}$ & $3,13 \mathrm{a}$ \\
$\mathrm{D}=0,15-24$ & $15,63 \mathrm{a}$ & $0,00 \mathrm{a}$ & $64,06 \mathrm{a}$ & $90,63 \mathrm{a}$ & $64,06 \mathrm{a}$ & $20,31 \mathrm{~b}$ & $1,56 \mathrm{a}$ & $4,69 \mathrm{a}$ \\
$\mathrm{E}=0,05-48$ & $15,63 \mathrm{a}$ & $1,56 \mathrm{a}$ & $53,13 \mathrm{a}$ & $95,31 \mathrm{a}$ & $67,19 \mathrm{a}$ & $23,44 \mathrm{c}$ & $0,00 \mathrm{a}$ & $4,69 \mathrm{a}$ \\
\hline
\end{tabular}

Keterangan: Angka rata-rata yang diikuti huruf yang sama berbeda tidak nyata berdasarkan Uji Jarak Berganda Duncan pada taraf nyata $5 \%$.

Hasil analisis menunjukan bahwa perlakuan pemberian kolkisin tidak berpengaruh terhadap kontaminasi pada planlet terung haploid, kontaminasi diduga karena faktor eksternal yakni kebersihan lingkungan, alat-alat atau bahan kultur nya. Gunawan (2007) 
mengemukakan bahwa kontaminasi terjadi karena lingkungan yang tidak steril, kontaminan sudah memenuhi seluruh botol kultur atau eksplan yang tertutup kontaminasi.

Pemberian kolkisin dengan berbagai konsentrasi dan lama inkubasi tidak berpengaruh nyata terhadap planlet berkalus. Walaupun tidak berbeda nyata Persentase berkalus yang tertinggi terdapat pada perlakuan pemberian kolkisin yang rendah dan lama inkubasi yang rendah. Semakin lama perlakuan maka semakin lama pula eksplan berkalus, hal ini diduga disebabkan menyerapnya kolkisin ke seluruh bagian eksplan sehingga proses pembelahan sel terganggu. Pembelahan sel menjadi lambat disebabkan oleh jumlah kromosom yang mengganda (Suryo, 2007).

Jumlah akar terbanyak dihasilkan oleh perlakuan A atau tanpa pemberian kolkisin. Walaupun tidak berbeda nyata dengan perlakuan lainnya perlakuan A menghasilkan planlet berakar lebih banyak. Jumlah akar yang tumbuh pada perlakuan B, C, D, E, F dan G desebabkan karena adanya penghambatan pertumbuhan akar, Pemberian kolkisin menyebabkan rentang waktu pertumbuhan akar menjadi panjang (Fajrina et al., 2012).

Pemberian beberapa konsentrasi kolkisin dan lama inkubasi tidak berpengaruh terhadap tingkat planlet hidup tanaman terung haploid. Kolkisin menyebabkan partumbuhan menjadi lambat dan morfologi jadi abnormal. Gejala itu merupakan gejala yang umum terjadi setelah perlakuan kolkisin pada tanaman (Griesbach, 1981). Apabila konsentrasi kolkisin terlalu tinggi dengan inkubasi yang terlalu lama maka senyawa kolkisin akan memperlihatkan efek negatif yaitu penampilan tanaman menjadi tidak bagus, sel-sel pada tanaman rusak hingga dapat menyebabkan kematian (Sirajuddin et al., 2017).

Pemberian kolkisin pada planlet terung memberikan pengaruh berbeda nyata terhadap jumlah planlet haploid. Planlet terung haploid yang tidak diberi perlakuan kolkisin (kontrol) tetap akan menjadi haploid karena pembelahan sel pada saat mitosis tidak mengalami gangguan sehingga jumlah kromosomnya tetap haploid. Sedangkan yang diberikan perlakuan kolkisin pembelahan sel terganggu yaitu pembentukan benang spindle terganggu sehingga kromosom yang telah berpisah dari sister kromatidnya tidak tertarik kearah kutub dan tidak terjadi pembelahan sel atau sitokinesis. Akibatnya jumlah kromosom dalam satu sel mengganda. Planlet haploid yang telah diberi perlakuan kolkisin masih tetap menjadi haploid kemungkinan dikarenakan perlakuan yang kurang optimal. Konsentrasi kolkisin dan lama inkubasi yang belum tepat tidak akan mengakibatkan penggandaan kromosom (Sirajuddin et al., 2017).

Pemberian kolkisin pada planlet terung haploid dengan konsentrasi 0,05\% dengan lama inkubasi 48 jam dan pemberian kolkisin dengan konsentrasi 0,1\% dengan lama inkubasi 48 jam memberikan pengaruh nyata terhadap duplikasi kromosom dari haploid menjadi haploid ganda. Pemberian kolkisin menyebabkan terhambatnya kerja mikrotubulus, yang selanjutnya menghambat terbentuknya benang spindle. Karena benang spindel tidak terbentuk, maka kromosom yang sudah berpisah dari sister kromatidnya tidak tertarik ke arah kutub berlawanan dan mengalami mengalami gagal berpisah akibatnya kromosom mengalami penggandaan tetapi tidak diikuti dengan pembelahan sel (Fatkhurrahman, 2016).

Pemberian beberapa konsentrasi kolkisin dan lama inkubasi tidak berpengaruh terhadap planlet triploid. Hal ini disebabkan karena konsentrasi kolkisin dan lama inkubasi. Jika konsentrasi kolkisin dan lama waktu perlakuan kurang mencapai keadaan yang tepat, maka poliploidi belum dapat diperoleh (Suryo, 2007). Pada pembacaan tingkat ploidy menggunakan mesin Flowcytometry Guava, pemberian kolkisin pada planlet terung haploid tidak berpengaruh nyata terhadap pembacaan yang hasilnya tidak terbaca. Pemberian kolkisin pada tanaman 
diharapkan dapat meningkatkan tingkat ploidy tanaman. Peningkatan tingkat ploidy ini salah satunya dapat memperbesar bagianbagian tanaman (akar, batang, daun, bunga dan buah) tetapi pada penelitin ini perlakuan pemberian kolkisisn menyebabkan ukuran daun lebih tebal. Sehingga pada proses cek ploidy, sampel sulit untuk di ekstrak sehingga hasil tidak dapat terbaca (Damayanti, 2007).

\section{KESIMPULAN}

Berdasarkan hasil percobaan bahwa konsentrasi kolkisin dan lama inkubasi berpengaruh terhadap duplikasi kromosom planlet terung haploid hasil kultur antera. Pemberian kolkisin pada konsentrasi $0,05 \%$ dengan lama inkubasi 48 jam dan konsentrasi kolkisin $0,1 \%$ dengan lama inkubasi 48 jam memberikan pengaruh nyata terhadap planlet haploid ganda.

\section{DAFTAR PUSTAKA}

Damayanti, F. 2007. Analisis Jumlah Kromosom Dan Anatomi Stomata Pada Beberapa Plasma Nutfah Pisang (Musa $\mathrm{Sp}$.). Bioscientiae 4(2): 53-61. https://www.google.com/url?sa=t\&rct=j\&q $=\&$ esrc $=$ s\&source $=$ web $\& c d=\& v e d=2 a h U$ KEwjv4vGxhb7uAhVDeysKHf3VCj8QFj AAegQIBRAC\&url=http\%3A\%2F\%2Fppj p.ulm.ac.id\%2Fjournals\%2Findex.php $\% 2 \mathrm{~F}$ bioscientiae $\% 2$ Farticle $\% 2$ Fdownload $\% 2 \mathrm{~F} 1$ 63\%2F146\&usg=AOvVaw0QzVLDmTqk 6MBTt-6EmIPA.

Fajrina, A., M. Idris, N.W. Surya, L. Riset Genetika, J. Biologi, et al. 2012. Penggandaan Kromosom dan Pertumbuhan Somaklonal Andalas (Morus macroura Miq. var macroura) yang Diperlakukan dengan Kolkisin Duplication of chromosome and the growth of andalas (Morus macroura Miq. var macroura) somaclone with colchicine treatment. J. Biol. Univ. Andalas (J. Bio. UA.) 1(1): 23-26. doi: https://doi.org/10.25077/jbioua.1.1.\%25p.2 012.

Fatkhurrahman. 2016. Produksi Tanaman Haploid Ganda Melalui Kultur Ovari. Buku Tahunan Bioteknologi, PT. East West Seed Indonesia.

George, E.F., M.A. Hall, and G.-J.A. Klerk. 2008. Morphogenesis and haploid plants.

Griesbach, R.J. 1981. Colchicineinduced Polyploidy in Phalaenopsis orchids.

Gunawan, L.W. 2007. Teknik Kultur Jaringan Tanaman.

Kasha, K.J., and M. Maluszynski. 2003. Production of doubled haploids in crop plants. An introduction. https://www.springer.com/gp/book/978140 2015441.

Kementan. 2017. Statistik Pertanian. Kementrian Pertanian Republik Indonesia.

Mulyana. 2016. Produksi Tanaman Semangka Tetraploid. Buku Tahunan Bioteknologi, PT. East West Seed Indonesia.

Pitojo, S. 2010. Benih Cabai. Indonesia One Search by PERPUNAS. Yogyakarta. p. 2653

Poehlman, J.M., and D.A. Sleper. 2015. Breeding Field Crops. Edition, 4Th. Lowa State University Press/Ames. p. 1-27

Seguí-Simarro, J.M. 2010. Androgenesis Revisited. Bot. Rev. 76(3): 377-404. doi: 10.1007/s12229-010-9056-6.

Sirajuddin, T. Rahayu, and S. Lailis. 2017. Pengaruh Pemberian Berbagai Konsentrasi Kolkisin dan Lama Perendaman terhadap Respon Fenotipik Zaitun (Olea europaea). e-Jurnal Ilm. BIOSAINTROPIS 2(2): 3641.

https://www.google.com/url?sa=t\&rct=j\&q $=\&$ esrc $=\mathrm{s} \&$ source $=$ web $\& c d=\& v e d=2 a h U$ KEwi4vceejb7uAhXI7HMBHXZWBRwQ FjAAegQIBRAC\&url=http $\% 3 \mathrm{~A} \% 2 \mathrm{~F} \% 2 \mathrm{Fb}$ iosaintropis.unisma.ac.id\%2Findex.php $\% 2$ Fbiosaintropis\%2Farticle\%2Fdownload\%2 F55\%2F43\&usg=AOvVaw3a3It5DnjxeK_ 
AnMQat6cj.

Solmaz, I., N. Sar, I. Gürsoy, and S. Kasapoğlu. 2011. Comparison of in vivo and in vitro colchicine application for production of dihaploid "kirkagac" and "yuva hasanbey" melons. African J. Biotechnol. 10(70): 15717-15724. doi: 10.5897/AJB11.2445.

Suminah, Sutarno, and A.D. Setyawan. 2002. Induksi Poliploidi Bawang Merah (Allium ascalonicum L.) dengan Pemberian Kolkisin. Biodiversitas, J. Biol. Divers. 3(1): $\quad 174-180 . \quad$ doi: 10.13057/biodiv/d030102.

Suryo, H. 2007. Sitogenetika. Yogyakarta.

Yanik, A.N. Sugiharto, and Respatijarti. 2017. Pengaruh Waktu Polinasi dan Umur Polen Terhadap Hasil Benih Terong Hijau (Solanum melongena L .) Hibrida. J. Produksi Tanam. 5(2): 265-272. https://www.google.com/url?sa=t\&rct=j\&q $=\&$ esrc $=$ s $\&$ source $=$ web $\& c d=\& c a d=$ ja $\& u a$ $\mathrm{ct}=8 \& \mathrm{ved}=2 \mathrm{ahUKEwj} 7 \mathrm{p} 821 \mathrm{hMDuAhUTy}$ jgGHUeMCOwQFjAAegQIBhAC\&url=htt ps $\% 3 \mathrm{~A} \% 2 \mathrm{~F} \% 2 \mathrm{Fmedia}$.neliti.com\%2Fmedi a\%2Fpublications\%2F190317-ID-

pengaruh-waktu-polinasi-dan-umur-polent.pdf\&usg=AOvVaw0t.

Yetisir, H., and N. Sari. 2003. A new method for haploid muskmelon (Cucumis melo L.) dihaploidization. Sci. Hortic. (Amsterdam). 98(3): 277-283. doi: 10.1016/s03044238(02)00226-1. 